\title{
L'État irlandais et les aides humanitaires destinées au peuple espagnol durant la guerre civile espagnole
}

Pere Soler Paricio

\section{(2) OpenEdition \\ Journals}

Édition électronique

URL : http://journals.openedition.org/etudesirlandaises/5641

DOI : 10.4000/etudesirlandaises. 5641

ISSN : 2259-8863

Éditeur

Presses universitaires de Caen

\section{Édition imprimée}

Date de publication : 18 décembre 2018

Pagination : 53-76

ISBN : 978-2-7535-7693-3

ISSN : 0183-973X

Référence électronique

Pere Soler Paricio, "L'État irlandais et les aides humanitaires destinées au peuple espagnol durant la guerre civile espagnole », Études irlandaises [En ligne], 43-2 | 2018, mis en ligne le 01 novembre 2018, consulté le 13 septembre 2019. URL : http://journals.openedition.org/etudesirlandaises/5641 ; DOI : 10.4000/etudesirlandaises.5641 


\title{
L'État irlandais et les aides humanitaires destinées au peuple espagnol durant la guerre civile espagnole
}

\author{
Père Soler Paricio \\ Université de Bretagne Sud
}

\section{Résumé}

La guerre civile espagnole, qui eut lieu entre 1936 et 1939, compliqua l'agenda politique du Gouvernement irlandais, l'obligeant à gérer un grand nombre de situations, parmi lesquelles les demandes d'assistance au peuple espagnol que plusieurs organismes avaient fait parvenir au Taoiseach. Que ce soit pour des motifs idéologiques, étant donné la conjoncture internationale, ou en raison d'un pur intérêt électoraliste, l'exécutif du Fianna Fáil répondit négativement à la majorité des demandes. Cet article expose la chronologie factuelle des faits et des motivations particulières qui accompagnèrent la dialectique contradictoire qui s'établit entre les différents interlocuteurs.

Mots clés : guerre civile espagnole, Free State/Éire, aide humanitaire, Seconde République Espagnole/Espagne nationaliste, Eamon De Valera, Joseph Walshe.

\section{Abstract}

The Spanish Civil War, 1936-1939, aroused some political difficulties that the Irish Government had to face, among others, the humanitarian demands of assistance to the Spanish people that were sent to the Taoiseach. Ideological reasons, the international situation or electioneering interests explain the response of Fianna Fail executive, that rejected the bulk of the requests. This article surveils the encountered dialog that was established between the different interlocutors, each one of them putting forward his own concern.

Entre 1936 et 1939, la démocratie espagnole plongeait dans un affrontement fratricide qui aboutirait à l'élimination du jeune régime républicain et à l'instauration d'une longue dictature militaire. De l'autre côté de la mer Cantabrique, un nouveau venu dans le concert des nations, l'Irish Free State, se cramponnait non sans difficultés sur le chemin de l'émancipation et de la modernité. L'indépendantisme constitutionnaliste incarné par le Fianna Fáil et son dirigeant, Eamon de Valera, tentait de cimenter les bases d'un État républicain de fait sur lequel planaient de lointains nuages orageux. Érin, île d'Émeraude, devait lutter contre ses propres démons, qui étaient nombreux. Un douloureux partage 
frontalier au nord avait séparé l'Ulster des vingt-six comtés du sud, alimentant ainsi un pénible conflit interreligieux qui perdurerait jusqu'à la fin du siècle. Le souvenir de la guerre civile irlandaise, lutte fratricide qui avait opposé les pro-Traité aux anti-Traité, divisait la société et enracinait l'usage de la violence à des fins politiques. La pénurie et l'émigration obscurcissaient l'existence de la paysannerie et des classes populaires qui habitaient dans les misérables quartiers ouvriers des villes. Quelques améliorations étaient entrevues sur le plan économique et Dublin, sans aucun doute, véhiculait une aura cosmopolite qui reflétait une avancée sur le plan culturel. Cependant, un grave conflit douanier avec le Royaume-Uni ralentissait l'avenir commercial du pays, qui devait parvenir à une nouvelle alliance avec la Grande-Bretagne afin de renégocier les bases de leur relation mutuelle et de régler plusieurs problématiques urgentes ${ }^{1}$. Les difficultés provenaient aussi de l'extérieur. L'agitation politique qui rythma la valse de l'entre-deux guerres perturba la paix sociale de l'île, où fleurit une manifestation endogène du fascisme, les blueshirts, qui semblait être appelée à se développer partout. Géante aux pieds d'argile, bien que cette organisation ait su utiliser la peur rouge prêchée par l'Église et l'opposition conservatrice dans les années précédentes, le manque de consistance idéologique de son discours et les choix contestables de ses dirigeants condamnèrent rapidement à l'oubli les attentes du corporatisme celte ${ }^{2}$. Le nationalisme invétéré, pour sa part, se releva de la défaite et libéra le cri des balles dans les rues. En plus de cela, une partie significative de ses militants rejoignit le nouveau projet émancipateur du républicanisme progressiste; la lutte pour la souveraineté et la révolution sociale redevenaient les deux faces d'une même pièce ${ }^{3}$. Plus encore, l'ombre du Léviathan, qui vociférait des chants guerriers depuis le continent, éclipsait la lumière de l'horizon et annonçait de sombres temps à venir. La Couronne britannique conservait plusieurs ports sur le sol irlandais. Si le conflit européen, tant redouté, éclatait, la gueule de la bête engloutirait, selon toute probabilité, l'île des saints et des fous, et, de ce fait, la proto-indépendance de la patrie pour laquelle les pères fondateurs de la nation venaient de verser leur sang.

La guerre civile espagnole compliqua l'agenda politique du Fianna Fáil, et les réactions contrastées que le conflit provoqua parmi les groupes de pouvoir du Free State contrarièrent le Gouvernement. L'exécutif de Dublin approuva, avec diligence, le Pacte de non-intervention qui, selon De Valera, qui en plus d'occuper le poste de Taoiseach s'occupait aussi du portefeuille ministériel des affaires étrangères, se présentait comme étant la meilleure stratégie afin d'éviter que le conflit

1. Francis Mac Manus (ed.), The years of the great test, 1926-39, Dublin/Cork, 1978.

2. Mike Cronin, The Blueshirts and Irish Politics, Dublin, Four Courts Press Ltd., 1997, p. 1-17.

3. Richard English, "Socialism and republican schism in Ireland: the emergence of the Republican Congress in 1934”, Irish Historical Studies, Vol. 27 No 105, May 1990. 
espagnol ne déclenche un conflit à l'échelle européenne ${ }^{4}$. L'abstention du pays dans les conflits extérieurs devint, de fait, une obsession du chef du Gouvernement, dans le but de préserver la souveraineté du Free State, ainsi que son fragile statut international'. Le Fine Gael, parti majoritaire de l'opposition, l'Église, la presse conservatrice et plusieurs municipalités s'opposèrent âprement à cette politique. Ils réclamèrent tous l'arrêt des relations commerciales et diplomatiques avec la République espagnole ainsi que la reconnaissance de Franco ${ }^{6}$. La droite extraparlementaire critiqua durement la politique du Taoiseach et éleva des obstacles qui aidèrent la cause du Généralissime, de plus, elle organisa un corps expéditionnaire qui s'unit aux troupes rebelles, compliquant grandement le dossier espagnol$^{7}$. La gauche radicale, bien qu'en nombre réduit et attaquée par ses rivaux, mit en place une active campagne de défense des forces loyalistes et envoya ses meilleurs éléments dans les rangs des Brigades Internationales ${ }^{8}$. De Valera et ses ministres assistaient, stupéfaits, à l'hostilité croissante qui s'intensifiait entre les anciens blueshirts et le républicanisme armé en raison d'un confus et lointain conflit. La conflagration espagnole menaçait de rouvrir les plaies mal cicatrisées de la guerre civile irlandaise. En plus de cela, un ambigu mouvement d'inspiration catholique et teinté d'aspects politiques, l'Irish Christian Front, parvint à mobiliser les foules en faveur des insurgés au moyen d'un discours anticommuniste efficace. Leurs meetings, très fréquentés, réunirent plus de 40000 personnes à Cork et à Dublin respectivement ${ }^{9}$.

La campagne électorale qui précéda l'élection générale de 1938 relégua la guerre d'Espagne à un second plan. Ensuite, l'indiscutable victoire dans les urnes du parti de Valera donna au Premier Ministre assez de crédit politique pour faire passer la nouvelle Constitution, ainsi que pour négocier avec l'Angleterre la restitution des ports et en finir avec le conflit douanier. Les affaires intérieures, liées à l'économie, aux relations avec la Grande-Bretagne et à l'évolution constitutionnelle du pays, monopolisèrent le débat public et refroidirent les passions que la guerre civile espagnole avait déchaînées. Néanmoins, ce conflit obligea le Gouvernement de l'Éire à gérer un bon nombre de problématiques qui sollicitèrent plusieurs Départements d'État et la détermination de leurs agents consulaires.

4. Bowyer J. Bell, "Ireland and the Spanish Civil War, 1936 to 1939”, in H. Gustav Klaus (ed.), Strong Words, Brave Deeds. The Poetry, Live and Times of Thomas O'Brien. Volunteer in the Spanish Civil War, Dublin, The O'Brien Press, 1994, p. 248-250.

5. Diarmaid Ferriter, Judging Dev: A reassessment of the life and legacy of Eamon de Valera, Dublin, Royal Irish Academy, 2007, p. 129.

6. Fearghal McGarry, Irish Politics and the Spanish Civil War, Cork, Cork University Press, 1999, p. 202-211.

7. Eoin O’Duffy, Crusade in Spain, Dublin, Browne and Nolan Limited, 1938.

8. Michael O'Riordan, Connolly Column. The story of the Irishmen who fought for the Spanish Republic, 1936-1939, Dublin, Warren \& Pell Publishing, 2005.

9. Robert Stradling, The Irish and the Spanish Civil War 1936-1939, Crusades in conflict, Manchester, Mandolin, p. 7-14. 
Lévacuation des compatriotes qui se trouvaient sur le terrain, le transfert et la protection du bureau de représentation du Free State à Madrid, le maintien ou l'arrêt des relations diplomatiques avec chacun des camps rivaux, l'échange commercial avec ses ports, la persistance de l'activité de pêche dans les eaux irlandaises par les flottes de Cantabrie ou le rapatriement des volontaires qui s'étaient lancés dans la lutte, ne sont que quelques exemples des nombreux dossiers que la guerre d'Espagne imposa à l'agenda de l'exécutif irlandais. Malgré tout, en plus de la mise en application des mesures dictées par le Comité de non-intervention, le cabinet du Fianna Fáil dut faire face à de nombreuses et inattendues circonstances politiques, entre autres, les demandes d'aide au peuple espagnol que divers comités et organisations firent parvenir au Taoiseach.

Le Gouvernement irlandais répondit discrètement à ces demandes. À tel point que, selon la documentation entreposée au National Archive of Ireland, De Valera et ses ministres refusèrent les appels à l'aide formulés par des associations aussi célèbres que la Croix-Rouge Internationale. Dublin n'offrit son soutien qu'à une seule demande, celle de l'International Commission for the Assistance of Child Refugees in Spain. La raison d'État, plus que la miséricorde, conseilla de soutenir la demande de l'organisation, qui était sur le point de ne pas recevoir le montant total de la subvention que les autorités de l'Éire avaient convenu de donner. En effet, comme nous le verrons plus tard, certains officiels du ministère des Affaires Étrangères ainsi que du ministère des Finances émirent des réserves et contrarièrent l'approbation du dossier.

\section{Le National Joint Committee for Spanish Relief}

La première de ces demandes fut formulée par la duchesse Katherine Atholl, membre de la Chambre des Communes et présidente du National Joint Committee for Spanish Relief (NJC), plateforme qui prit, en Grande-Bretagne, la tête des initiatives solidaires avec les victimes de la guerre ${ }^{10}$. Au printemps 1937, ce comité organisa l'accueil en Angleterre de centaines d'enfants du Pays Basque dont les villages et les villes étaient bombardés par l'ennemi. Dans ce contexte, la direction du NJC envoya une lettre à De Valera, datée du 17 mai, qui demandait à l'exécutif de Dublin de financer les coûts de la campagne :

10. Quatre autres députés de la Chambre des Communes intégrèrent les instances de l'organisation, qui eut la parlementaire Eleanor Rathbone et le maire de Listowel pour vice-présidents. Le NJC, qui hébergeait un total de 150 associations et comités, déplaça son action humanitaire sur le terrain espagnol tout en animant en Angleterre les campagnes d'aide pro-républicaine. L'évacuation des enfants, l'établissement de colonies pour enfants et l'affrètement de bateaux chargés de nourriture constituèrent la plus grande partie de son activité. Source : "Aid to Spain” in Modern Records Centre (University Library) - University of Warwick [https:// www2.warwick.ac.uk]. 
Dear Prime Minister,

As you are no doubt aware, arrangements have been made for the admission of Basque refugee children in this country. It is the object of this Committee to receive as many children as possible, and owing to the continued bombardment of Bilbao and other Basque towns, the matter has become one of increasing urgency.

A substantial sum of money has already been raised in England for this purpose, and many organisations of widely differing opinions, are cooperating in the care of the children. The Archbishop of Westminster has personally expressed himself in full cooperation with the proposal, and is represented on the Committee, the Salvation Army, the Trades Union Congress and many other relief organisations are also cooperating.

We thought that your Government might perhaps like to cooperate in this humanitarian work, and we are therefore venturing to ask whether you could see your way to assisting us financially, or in any other manner you may think fit ${ }^{11}$.

Le bureau du Taoiseach transféra le dossier au ministère des Affaires Étrangères, chargeant ainsi Joseph Walshe d'informer le Haut-Commissariat irlandais à Londres sur la réponse qu'il devait transmettre au comité :

I should be glad if you would inform the Committee that no request has been received by the Irish Government to admit Basque or other Spanish refugee children into this country. Should such a request be received it would, of course, receive sympathetic consideration. You might add that you understand that considerable sums of money have been sent from Ireland to Spain for relief of the suffering poor in that country ${ }^{12}$.

L'État irlandais ne donna pas un sou au NJC, et son engagement à loger certains mineurs pouvait difficilement être respecté, puisque le dispositif d'accueil exigeait la coordination d'un vaste réseau de services volontaires qui ne pouvaient être pourvus qu'en Angleterre. De plus, l'exécutif de De Valera et le reste des chancelleries européennes savaient que le front du Nord était condamné, puisque la majorité des journaux du continent suivaient de près l'avancée des troupes rebelles sur la frange cantabrique; sous peu, il n'y aurait plus d'enfants à évacuer de ces zones. Tant et si bien qu'un mois après que le NJC avait remis sa lettre à De

11. National Archive of Ireland (ci-après NAI), Dept. For. Aff - 200 Series files - 243/7.

12. Les "considerables sums of money " auxquelles se réfèrent la note, font allusion aux $32000 £$ que l'Église catholique d'Irlande réunit grâce à une collecte, organisée à l'automne 1936, au profit des victimes de la guerre d'Espagne. L'argent récolté termina dans les mains des militaires rebelles, l'Irish Christian Front ayant joué un rôle trouble dans la remise de l'argent, ce qui souleva une grande polémique dans l'île. Hilari Raguer, $L a$ pólvora y el incenso. La Iglesia y la Guerra Civil española (1936-1939), Barcelona, Ediciones Península, 2001, p. 110-112. 
Valera, Bilbao tomba aux mains des insurgés. En octobre 1937 se termina la Campagne du Nord, qui signa la fin de l'occupation de la Cantabrie et des Asturies par l'armée franquiste.

\section{疄 La Croix-Rouge Internationale}

Un an plus tard, le Département des Affaires Étrangères ordonna à la Délégation irlandaise auprès de la Société des Nations, basée à Genève, de prendre contact avec l'International Commission for the Assistance of Child Refugees in Spain, une organisation à laquelle le Gouvernement de l'Éire avait promis d'accorder une subvention. Étant donné que l'agence de représentation ne réussit pas à joindre les responsables de la commission, le directeur du bureau essaya de les retrouver par l'intermédiaire du Comité de la Croix-Rouge Internationale qui travaillait dans la ville. Il se produisit alors un absurde malentendu qui mit en évidence la faible disposition du Saorstát à collaborer sur ce sujet.

$\mathrm{Au}$ printemps 1938, les difficultés financières menaçaient la poursuite du travail humanitaire que cet organisme mettait en œuvre. Auparavant, l'assistance aux deux camps belligérants avait généré de telles frictions entre la CroixRouge espagnole et la Croix-Rouge Internationale que cette dernière s'était vue contrainte de nommer un délégué pour le territoire républicain, Junod, et un autre pour l'Espagne franquiste, le comte de Pourtalès. Le premier gardait un agent fixe à Barcelone pendant que le second gardait un subordonné à SaintSébastien, ce qui garantissait sa liberté de mouvement. L'engrenage était complété par une agence à Saint-Jean-de-Luz dirigée par Muntadas, assistant du Comte de Pourtalès. Le manque de moyens remettait en question le maintien de cette structure et par conséquent, le travail que l'organisation fournissait en Espagne. Cette question serait débattue à Londres, le 19 juin, dans le cadre du congrès organisé par la Croix-Rouge Internationale; faute de nouvelles subventions il faudra se passer des services des agents de Barcelone et de Saint-Sébastien. Lorsque la Délégation irlandaise de Genève prit contact avec l'organisation, certainement au sujet de la distribution d'une aide financière, elle fit penser au bureau de la Croix-Rouge que l'exécutif du Fianna Fáil avait l'intention de lui faire un don. Le 8 juin, le délégué du Saorstát informa le ministère des Affaires Étrangères de la situation, assurant qu'il avait rectifié son erreur auprès du Comité de l'organisation et que tous les doutes semés par la confusion initiale avaient été dissipés. Malgré cela, deux jours plus tard une responsable de la Croix-Rouge Internationale, Odier, téléphona depuis la Suisse au Représentant irlandais en Espagne, Leopold Kerney, dont le bureau avait été déplacé, comme tant d'autres agences de représentation, à Saint-Jean-de-Luz. Selon ce que le diplomate rapporta par la suite à ses supérieurs, Odier "stated that she had heard that there were rather 
bright prospects of financial assistance from Ireland. She did not make herself any more precise than that ${ }^{13}$ ". De plus, le matin suivant, obéissant aux instructions du Comte de Pourtalès, Muntadas rendit visite à Leopold Kerney pour, selon ses propres mots, "securing my friendly intervention with my Government on behalf of the International Red Cross ${ }^{14}$ ". L'Éire avait confirmé la présence de certains représentants au congrès que devait prochainement tenir la Croix-Rouge Internationale à Londres. Le rapport du représentant confirmait que l'imbroglio pourrait compliquer la mission de la délégation irlandaise :

[...] at the beginning of our conversation, was apparently for a donation which would help to keep the organisation going as at present pending the expected decision of the Congress, but, as we finished our talk, I gathered that its principal purpose was to acquaint you in advance with the position so that your delegate at the Congress on 19th June would go prepared to voice your desire to make a financial contribution for the desired purpose ${ }^{15}$.

Le ministère des Affaires Étrangères rapporta à son délégué à Genève la persistance du malentendu :

[...] Although it is stated in your minute under reference that you had already explained the error to the Red Cross Bureau in order that they might not expect a contribution from the Irish Government, it is feared that that explanation may not have been fully understood [...] it appers that the Committee's hope of financial assistance from Ireland are in no way diminished ${ }^{16}$.

De Valera avait résolu la question de manière définitive : "In view of the fact that this country has not yet formed a national Red Cross Society, the Minister would not care to recommend a State grant to the International Body's funds as suggested ${ }^{17}$ ”. Selon cette instruction, en plus d'expliquer, en ce qui concerne l'organisation, que le gouvernement irlandais ne ferait aucune donation, le diplomate devait faire en sorte que la question ne soit pas soulevée au congrès de Londres : "As you are possibly aware, two observers from the Department of Defence will attend the forthcoming Congress of the Red Cross Society at London and it is desired that they may not be importuned in the matter of an Irish contribution to the Committee's work in Spain ${ }^{18}$. " À en juger par la documentation, la participation à l'événement des attachés militaires se conclut sans incident. À la fin de ce même congrès, et après que le délégué irlandais à Genève avait exprimé une fois encore la position de son

13. NAI, Dept. For. Aff - 200 Series files - 243/7.

14. Ibid.

15. Ibid.

16. Ibid.

17. Ibid.

18. Ibid. 
Gouvernement au sujet de la Croix-Rouge Internationale, le bureau central de l'organisation transmit le message à Odier, qui jusqu'alors n'avait pas été informée du malentendu. Selon le rapport que l'agence de représentation remit au Département des Affaires Étrangères le 30 juin, l'affaire était close : "So far as the Red Cross people here are concerned it may be taken that the misunderstanding has been completely dissipated ${ }^{19}$."

\section{Irish Foodship for Spain Committee}

L'Irish Foodship for Spain Committee fut constitué à la suite de la réunion tenue au Molesworth Hall de Dublin début janvier 1939. Le révérend et ancien dirigeant du Sinn Féin Michael O’Flanagan en fut nommé président. Le républicain Patrick Byrne et le communiste Robin Tweedy occupèrent, respectivement, les fonctions de trésorier et de secrétaire. Par la suite, Frank Edwards, représentant du Republican Congress, le professeur Rudmose Brown, la célèbre républicaine Maud Gonne McBride et d'autres figures du spectre progressiste irlandais firent partie d'une vice-présidence partagée. L'objectif de l'organisation consistait à collecter des vêtements et des provisions pour les envoyer à Belfast, où un comité homologue affréterait un bateau chargé d'aide humanitaire à destination du peuple espagnol. Selon le communiqué envoyé à la presse, le nouvel organisme désirait " to stress the humanitarian nature of its appeal, and its sole aim is to relieve the suffering of the non-combatant population. It appeals to all those who differ on the issues in the Spanish war, the women, children and the aged "20 ". Le comite dut répondre aux critiques formulées par les détracteurs de l'Espagne républicaine dans les journaux pro-franquistes comme Irish Independent. Les invectives reprochaient à la plateforme que sa campagne ne profite exclusivement qu'au territoire loyaliste et, dans le pire des cas, la possibilité que des armes soient cachées dans le navire était envisagée. Tant et si bien que Patrick Byrne fut contraint d'adresser une lettre à l'éditeur du journal conservateur dans laquelle il expliquait que les autorités nationales avaient refusé l'aide du comité, en même temps qu’il invitait toute personne qui le désirerait à inspecter le bateau au départ de Belfast avant qu'il ne prenne la mer ${ }^{21}$.

Le 16 janvier 1939, le secrétaire du comité envoya une demande d'aide au nouveau Président du pays Douglas Hyde, intellectuel reconnu de confession protestante et ancien militant du Sinn Féin. Le message dactylographié disait ceci :

19. Ibid.

20. Irish Press, 6 janvier 1939.

21. Irish Independent, 14 janvier 1939. 
I enclose circular outlining the terms of our campaign to send a contribution from the people of the South towards the Irish Foodship which leaves Belfast at the end of the month.

The Belfast Committee, of which the Earl of Antrim is president and His Grace the Bishop of Down and Connor, and Professor Henry of Queen's University, are vice-presidents, has been working for several weeks.

My Committee feels sure that you will be in entire agreement with this humanitarian work. Conditions are so severe in parts of Spain that even hospitals are without soap and milk.

We trust Your Excellency will excuse the liberty in writing to you, but we believe that you will be eager to assist us in our efforts to alleviate much unnecessary suffering 22 .

Au vu de la constante inhibition du cabinet De Valera face à la guerre d'Espagne et de sa réticence à s'impliquer dans les campagnes d'aide humanitaire, les dirigeants de l'organisation durent penser que Hyde serait un meilleur interlocuteur, étant donné ses anciennes convictions républicaines et la réserve dont il faisait toujours preuve, au vu de sa foi, face aux disputes sectaires. Ainsi que l'évoque la copie du pasquin paraphé par le révérend Michael O’Flanagan que nous reproduisons ci-après, l'appel du comité était adressé aux citoyens des deux côtés de la frontière, au-delà de leurs convictions politiques et de leur religion :

Dear Friend.

Do you know that there are famine areas in Spain; that disease is spreading because of scarcity of soap; that there is an appaling shortage of clothing? Now, that knowledge of this conditions is rapidly spreading, Irishmen and women who differ on the issues in the Spanish War feel bound to come together quickly to help in the fight against famine and disease. In this we are only keeping abreast of charitable people in other lands. America is giving generously. France is doing a great deal. Scotland has sent a shipment of food. So has England. And now Belfast, through a Committee of which Lord Antrim is chairman, gives Ireland a lead by announcing that the people of that city will send a foodship by the end of January. Believing that the South of Ireland will be eager to help in the good work initiated by Belfast, a Committee has come together quickly in Dublin. I appeal to you in the name of that Committee to give what you can and to give quickly. Our appeal is for Food. Soap. Clothing: a tin of milk. A pair of socks. A blanket-Can you help? Then please make up your parcel now. Our collector will call in a day or two to take it to our depot.

22. NAI, Secrt. of the Pres. -Registered files- PRES 1/P 1165. 
To doctors and chemists we appeal for medecines and dressings. Governments should intervene to remedy famine but international politics make governments hesitant and nervous. Only the people are free to move quickly and in great force, for to them politics are nothing in face of starvation and disease. In the name of our common humanity I appeal to all sections of the Irish people to give generously and quickly.

On behalf of the Organising Committee in the South of Ireland for a Foodship to Spain ${ }^{23}$.

Tandis qu'une petite flotte d'aide humanitaire composée de dix-sept navires partait d'Angleterre et que la campagne en Irlande atteignait sa troisième semaine, le Metropolitan Hall de Dublin accueillit dans la nuit du 18 janvier 1939 un meeting comble de l'Irish Foodship for Spain Committee. En plus de recevoir les dons de plusieurs particuliers et de quelques collectifs comme les dockers du port, Patrick Byrne remercia Irish Times et Evening Mail pour leur collaboration. Accompagné par le leader du Republican Congress, Peadar O’Donnell, le secrétaire du comité souligna qu'ils avaient jusqu'alors reçu de l'équipement et des souscriptions en espèces pour une valeur totale de 300 livres sterling; les contributions les plus significatives provenaient de religieux protestants. Face aux détracteurs de l'initiative, il précisa, ensuite, que les comptes de l'organisation étaient disponibles pour toute demande d'inspection, et qu'il était ainsi possible de vérifier comment était dépensé l'argent ${ }^{24}$.

Le 21 janvier, le secrétariat de la Présidence fit savoir à Patrick Byrne que Douglas Hyde s'était temporairement absenté de son poste. À son retour, la lettre du comité lui serait remise. En réalité, les conseillers du dignitaire voulaient gagner du temps dans le but d'étudier la composition de la plateforme et la nature de leurs activités. Cette semaine-là, alors que les adhérents de l'association parcouraient en fourgonnette les provinces de l'Éire pour récupérer les dons dans quarante-neuf communes différentes, les subalternes du Uachtarán rédigèrent une note interne qui déconseillait de soutenir le comité en raison des sympathies de gauche de ses membres ${ }^{25}$. Les républicains Michael O'Flanagan et Peadar O’Donnell, ce dernier étant leader du Republican Congress, étaient accusés d'être communistes. Ni l'un ni l'autre ne faisaient partie de l'Irish Communist Party, bien que tous deux aient pris part à la défense de la République espagnole. La note rédigée par le secrétariat de la Présidence signalait que le révérend venait de visiter le territoire loyaliste. En effet, à la fin de l'année 1938, O'Flanagan alla à Barcelone, où il offrit un entretien à un reporter du journal La Vanguardia; il se rendit quelques

23. Ibid.

24. Irish Times, 19 janvier 1939. Irish Press et le journal de Lombard Murphy rendirent aussi compte de ce qu'il s'était passé. Irish Independent, 19 janvier 1939, p. 12; Irish Press, 20 janvier 1939, p. 2.

25. Concernant la récolte des dons dans les comtés ruraux, voir Irish Times, 24 janvier 1939. 
jours plus tard à Madrid. L'ancien prêtre défendit la cause républicaine sur le sol espagnol, en Irlande et aux Etats-Unis d'Amérique ${ }^{26}$. Peadar O'Donnell participait activement aux actes de soutien et aux campagnes de solidarité en faveur de la République espagnole organisés par les partis politiques de gauche en Irlande. De même, il avait été témoin in situ de l'éclatement de la guerre civile espagnole, reportant cet événement dans une chronique publiée en 1937 et dans laquelle il défendait la cause loyaliste ${ }^{27}$. Robin Tweedy, décrit dans la note comme étant sympathisant communiste, appartenait quant à lui à l'Irish Communist Party. Parmi les diverses activités de soutien au camp loyaliste dans lesquelles il prit part, on remarque particulièrement son rôle dans la mise en place du Spanish Medical Aid Committee, une organisation créée en septembre 1936 dans le but d'aider la République espagnole sur le plan médical ${ }^{28}$. Michael O'Flanagan, Peadar O’Donnell et Robin Tweedy étaient, ainsi, les membres actifs du comité de Dublin qui déconseillaient d'approuver, d'après le secrétariat de la Présidence, la demande de l'Irish Foodship for Spain Committee. Les personnalités qui faisaient partie du comité de l'organisation installé à Belfast inspiraient une plus grande confiance aux subalternes du Uachtarán. Cependant, l'accusation de communiste qui pesait sur le cercle de Dublin, et le fait que les approvisionnements étaient destinés uniquement au territoire gouvernemental, fournissaient des arguments aux détracteurs de la demande. Ainsi l'annonce le document en question :

\section{The names associated with the Irish Foodship for Spain Committee do not inspire confidence.}

2. The President, Rev. Michael O'Flanagan, is a Republican of the extreme type in Ireland who is believed to have leanings towards communism. Mr. Tweedy who is associated with him as co-trustee, is also credited with communistic sympathies.

3. Fr. O'Flanagan was recently in Barcelona, which is the headquarters of the communistic Government in Spain.

4. Another prominent person associated with the project is Peadar O'Donnell, who is also stated to have communistic leanings.

5. On the other hand, it is stated in paragraph 2 of the letter from the Committee, that the Earl of Antrim is President of the Belfast Committee, and His

26. Pere Soler, Irlanda y la Guerra Civil española. Nuevas perspectivas de estudio, Tesis Doctorals en Xarxa [http:// hdl.handle.net/10803/113554], p. 126-130. Concernant l'activité politique de Michael O'Flanagan tout au long de sa vie, voir, Denis Carrol, Unusual Suspects. Twelve Radical Clergy, The Columbia Press, 1998, p. 205245.

27. Concernant l'implication de Peadar O’Donnell dans les actes et campagnes de soutien à la République espagnole qui furent organisés en Irlande, voir Pere Soler, op. cit., p. 87-88, 126, 162, 164, 167, 172, 182, 184-189, 269, 370, 434, 512. Concernant la chronique qui relate son séjour en Espagne au commencement de la guerre civile, voir Peadar O’Donnell, Salud! An Irishmen in Spain, Methuen and Co. Ltd., London, 1937.

28. Pere Soler, op. cit., p. 163, 174. 
Grace the Bishop of Down and Connor (presumably the Protestant Bishop) and Prof. Henry of Queen's Unvy is also a member of the Committee.

6. Thus the composition of the Belfast Committee would at first sight seem to inspire more confidence that that of the Dublin Committee. Nevertheless, on account of the communistic hue of the Dublin Committee the President will not subscribe. Apart from this there is the bigger issue that to subscribe to a measure of this nature would be tantamount to the President taking sides between the two opposing parties in the Spanish Civil War, as it is perfectly clear that this ship is intended solely for the area controlled by the communistic Government in Spain ${ }^{29}$.

Le 24 janvier 1939, le secrétariat de la Présidence fit savoir à Patrick Byrne que Douglas Hyde avait refusé de satisfaire sa demande : "While the President is entirely in sympathy with any measure for the alleviation of distress and suffering, he regrets that he cannot see his way to subscribe to the project in question ${ }^{30}$." Le 28 janvier, la campagne s'acheva. Les dons collectés dans les vingt-six comtés du Sud avaient permis de réunir et/ou d'acheter une quantité totale de nourriture et de matériel médical dont la valeur atteignait les 600 livres sterling ${ }^{31}$. Trois camions remplis de provisions quittèrent Dublin en direction de Belfast le 30 janvier 1939. Douze membres de l'Irish Foodship Committee accompagnèrent les véhicules, sur lesquels étaient affichés les drapeaux de l'Irlande et de la République espagnole, ainsi que des affiches sur lesquelles on pouvait lire : "Irish aid will give you hope" et "Ireland helps war-torn Spain ". Après une longue pause à la frontière à cause de la Six-County Transport Act, la marchandise arriva dans la capitale de l'Ulster ${ }^{32}$. Une fois là-bas, le Northern Ireland Joint Committee for Spanish Relief rassembla le chargement avec les provisions et le matériel qui avaient été collectés dans le Nord, dans l'attente de pouvoir embarquer la cargaison dans le bateau qui transporterait la marchandise vers le territoire loyaliste ${ }^{33}$. Il faut signaler que quelques jours auparavant, le 26 janvier 1939, Barcelone avait été prise par les rebelles.

\section{圈 L'International Commission for the Assistance of Child Refugees in Spain et l'Internationale pour le Respect du Droit d'Asile et l'Aide des Réfugiés Politiques}

En janvier 1938, le juge et président de l'International Commission for the Assistance of Child Refugees in Spain, Michael Hansson, dirigeant aussi de la Nansen

29. NAI, Secrt. of the Pres. -Registered files- PRES 1/P 1165.

30. Ibid.

31. Irish Press, 27 janvier 1939, p. 9.

32. Irish Press, 31 janvier 1939, p. 9.

33. Irish Independent, 31 janvier 1939, p. 9; 1er février 1939, p. 12. 
International Office for Refugees installée à Genève, se mit en contact depuis la Suisse avec le Secrétaire du Département des Affaires Étrangères, Joseph Walshe, dans le but de demander l'aide économique du Gouvernement irlandais pour financer la campagne solidaire que cette organisation prévoyait d'organiser ${ }^{34}$. Active dès la fin de l'année 1937, l'International Commission for the Assistance of Child Refugees in Spain déployait son action sur le terrain par l'intermédiaire d'associations et d'organismes étrangers qui accomplissaient des actions humanitaires à l'arrière-garde des deux camps opposés, en utilisant aussi les propres organisations espagnoles de secours social. La principale mission de la Commission était l'assistance aux enfants qui avaient abandonné leurs villes et villages pour fuir les bombardements, dont les familles ne pouvaient s'occuper, et qui vivaient dans des centres d'accueil disséminés dans toute l'Espagne. L'organisation estimait que 250000 enfants réfugiés étaient menacés par la faim et la misère. En réponse, l'International Commission for the Assistance of Child Refugees in Spain organisait une collecte internationale, dont l'argent collecté serait réparti de manière impartiale dans le territoire des deux camps belligérants, pour fournir aux enfants un repas chaud par jour pendant quatre mois. Hansson prit soin de préciser que le gouvernement britannique avait confirmé sa volonté de contribuer par un don de 25000 livres sterling, ce qui correspondait à un sixième du montant total requis pour financer l'opération ${ }^{35}$.

Quelques semaines plus tard, Hansson et Edith Pye, membre de l'International Commission et cadre du Friends Service Council, renouvelèrent leur demande ${ }^{36}$. En effet, le président de l'organisation envoya un télégramme en français dans lequel il assurait que "selon rapports récents situation véritablement catastrophique $e^{37}$ ", en même temps que la porte-parole des quakers anglais faisait savoir au ministère des Affaires Étrangères que la Nouvelle-Zélande et le Danemark avaient déjà annoncé leur entière disposition à contribuer à la campagne; la Suède, la Norvège et la Suisse soutinrent l'initiative quelques jours plus tard. Les autorités britanniques jouèrent une carte de défi, étant donné que la Dominions Office fit connaître à certains de ses agents consulaires le plan de l'International Commission, et l'adhésion à ce même plan de l'exécutif de Sa Majesté, dans le but qu'ils en informent les Gouvernements auxquels ils étaient accrédités. Dans ce contexte, le Haut-Commissariat irlandais à Londres fut mis en garde : «[...] the Under Secre-

34. Basée à Genève, l'International Commission for the Assistance of Child Refugees in Spain bénéficiait de l'appui de la Nansen International Office for Refugees déjà mentionnée, de l'International Migration Service (situé à Paris et à Genève), du Relief Work for Refugees (basé à Leeds), de l'Intergovernmental Advisory Commission for Refugees (dont les bureaux se trouvaient à Paris) et du Friends Service Council (basé à Londres).

35. NAI, Dept. For. Aff. -200 series files- 243/7.

36. Le Friends Service Council était un des comités centraux de la Britain Yearly Meeting of the Religious Society of Friends, l'organisation nationale des quakers en Angleterre.

37. NAI, Dept. For. Aff. -200 series files- 243/7. 
tary of State asks me to inform de Irish Government of the view which the British Government take of the scheme proposed by the Friends Service Council and the reply which they have given to the appea ${ }^{8}$ ". Le cabinet de Valera pourrait difficilement se dérober à la demande formulée par l'International Commission.

$\mathrm{Au}$ début du printemps, l'organisation avait détaché un commissaire sur le terrain, le suédois Malcolm de Lilliehöök, qui devait superviser l'activité embryonnaire de l'International Commission en Espagne. Un premier contingent de 15000 enfants, répartis des deux côtés du front, était déjà alimenté grâce à la Collecte Internationale. La France, la Belgique et l'Australie l'avaient rejointe, en plus du Dominion d'Afrique du Sud et la Commonwealth d'Australie, ce qui augmentait la pression morale et surtout politique que pouvaient ressentir les autorités irlandaises. De plus, les interlocuteurs cités plus avant renouvelèrent leurs appels. Ainsi de Michael Hansson, depuis Genève, qui fit parvenir une note à De Valera dans laquelle il annonçait :

The funds at the disposal of the Commission enable it to bring assistance only to this small proportion of the vast number of children in need of extra nourishment, whereas, according to recent reports received from Spain, it may be asserted without exaggeration that, in spite of the efforts of the authorities the health of thousands of children is threatened by the lack of sufficient food ${ }^{39}$.

Edith Pye en fit autant auprès de Joseph Walshe : "When we first issued an appeal, the Spanish refugee children were getting at least one meal a day; now we understand from our workers that there is not even this amount of food available and the situation is going from bad to worse ${ }^{40}$. " À son tour, le Haut-Commissariat irlandais à Londres informa que la Couronne continuait à réclamer, implicitement, l'intervention du cabinet du Fianna Fáil : " [...] a further letter which has been received in this connection from the Dominions Office ". L'insistance des intéressés se poursuivrait les mois suivants, laissant pour chacun des témoignages documentaires $^{41}$.

À la fin du mois de mai 1938, le futur représentant irlandais à Paris et à l'époque agent du ministère des Affaires Étrangères, Seán Murphy, transmit au Roinn Airgeadais (ministère des Finances) l'avis de De Valera. Il fallait contribuer à la collecte international, sinon " [...] owing to the official support already given or promised by other countries, a continued refusal on our part to contribute would reflect

38. Ibid.

39. Ibid.

40. Ibid.

41. Voir la lettre de Edith Pye datée du 26 mai, la Note Verbale du Haut-Commissionariat irlandais à Londres du 27 mai ainsi que du 5 août, et la lettre de Michael Hansson paraphée le 2 juin. Ibid. 
adversely on our international prestige ${ }^{42} "$; prenant comme référence la contribution du reste des Dominions, le Taoiseach détermina le montant de la donation : "Taking New Zealand as a fairly appropiate example, the Minister is of opinion that a contribution of $£ 2.000$ would [...] be regarded as quite adequate ${ }^{43}$ ". Le transfert de l'argent, issu du Fonds de Contingence de l'État, devait être ratifié par le ministère des Finances qui, par contre, formulerait quelques réserves et compliquerait l'approbation du dossier. Le représentant de ce ministère demanda au ministère des Affaires Étrangères qu'il lui fournisse des informations au sujet de la composition de l'International Commission, du travail qu'elle réalisait et de la façon dont étaient utilisés ses fonds. Encore plus significatif, il manifesta sa réticence en soulignant que le peuple irlandais avait déjà suffisamment démontré sa solidarité en prenant part aux collectes humanitaires que quelques organismes de l'île avaient organisées : "[...] it is presumed that your Department has borne in mind the contributions that have already been made, not through oficial channels, by the people of this country towards relief of ditress in Spain ${ }^{44}$ ". Ceci démontre à quel point le conflit espagnol avait divisé non seulement l'opinion publique mais aussi l'ensemble de la classe politique, une diversité de postures s'étant installée au sein du parti progouvernemental. En effet, trois députés du Fianna Fáil firent partie du ICF. À l'opposé, Hugo Flinn, secrétaire parlementaire du ministre des Finances irlandais, défendit tout au long du conflit la cause républicaine. De même, quelques mairies où le parti travailliste et le Fianna Fáil avaient établi un pacte de gouvernement approuvèrent des résolutions qui refusaient la souscription du Plan de Non-Intervention par De Valera, et plaidaient en faveur de la reconnaissance diplomatique du camp franquiste. En revanche, certaines branches locales du Fianna Fáil, comme celle de Killolane et Movidy (comté de Cork), prirent part aux campagnes de soutien à la République espagnole et approuvèrent des motions de solidarité en faveur de la cause loyaliste. Cependant, le groupe parlementaire du Fianna Fáil soutint toujours le Premier ministre irlandais dans tout ce qui concernait la guerre d'Espagne ${ }^{45}$.

Seán Murphy répondit en assurant que De Valera s’était plié à la demande de l'International Commission, à la condition que l'argent soit employé de manière impartiale pour venir au secours des enfants des deux camps opposés. Le Premier Ministre recommandait de donner dans un premier temps 1000 livres sterling,

\footnotetext{
42. Ibid.

43. Ibid.

44. En effet, en plus de l'important don qu'avait offert l'Église catholique d'Irlande, de nombreuses associations et organismes irlandais de bords politiques différents organisèrent des petites collectes tout au long du conflit, que ce soit pour venir en aide à la population civile comme en soutien aux volontaires étrangers qui luttaient en Espagne. Pere Soler, op. cit., p. 90-103.

45. Pere Soler, op. cit., p. 93-95.
} 
puis 1000 de plus à mesure que le reste des Gouvernements européens rendent effective la totalité de leur engagement ${ }^{46}$.

Le 11 août 1938, De Valera reçut dans son bureau Malcolm de Lilliehöök, qui venait le voir dans l'espoir d'obtenir l'aide tant convoitée. Deux jours plus tard, ce représentant de l'International Commission lui fit parvenir depuis Genève une note brève, qui résumait le travail effectué en Espagne par l'organisation depuis le lancement de sa campagne le $1^{\text {er }}$ mai 1938 , et il énumérait le nom des nations qui avaient souscrit au plan ainsi que la quantité d'argent que chacune d'entre elles avait apportée; l'Italie, la Croix-Rouge allemande et même l'Inde avaient réalisé un don. Grâce à la Collecte Internationale, 14000 enfants de Catalogne étaient nourris, 26000 dans le centre et le sud de la péninsule, et trois cantines étaient financées dans l'Espagne nationaliste. Avec l'arrivée de l'hiver, on estimait que 400000 enfants avaient besoin d'un apport complémentaire de nourriture. Le taux de mortalité parmi les enfants était, selon le rapport, "already heavy », leur pâleur et leur manque de vitalité sautaient aux yeux, et de très nombreux cas de malnutrition sévère étaient détectés ${ }^{47}$. En un mot, la situation était désespérée et le Gouvernement de l'Éire n'avait pas avancé un seul centime.

Après avoir rendu visite au Secrétaire Général de la Société des Nations, entrevue durant laquelle Malcolm de Lilliehöök fit part de ses rencontres avec De Valera et Lord Halifax, le représentant de l'International Commission se rendit, en compagnie de D. E. Blickenstaff, dirigeant de l'American Friends Service Committee (quakers américains), dans le bureau de Cremins, Délégué permanent de l'Irlande auprès de la Société des Nations à Genève. À partir de ce moment, cette agence de représentation consulaire devint une nouvelle scène de manœuvres où l'International Commission essaya de faire valoir ses intérêts auprès du Gouvernement de l'Éire. De son côté, l'exécutif du Fianna Fáil se servit aussi bien de Cremins que du Haut-Commissariat irlandais à Londres pour obtenir des informations complémentaires au sujet de l'organisation ${ }^{48}$.

Après l'élection générale qui avait vu le Fianna Fáil reprendre le pouvoir avec la majorité absolue, comptant depuis fin août sur l'accord du ministre des Finances pour une possible contribution de 2000 livres sterling, et étant donné la reprise de l'année parlementaire à partir du mois d'octobre 1938, De Valera et

46. NAI, Dept. For. Aff. -200 series files- 243/7.

47. NAI, Dept. For. Aff. -Secrt. Office- $\$ 2$.

48. Voir, entre autres, la Note Verbale remise par Cremins au Département des Affaires Étrangères le 31 octobre 1938, ainsi que les instructions transmises par ce ministère aux deux agents diplomatiques le 18 février 1939. Ces courriers abordent des questions aussi diverses que la remise en question de la foi religieuse dans laquelle étaient éduqués en Espagne les enfants accueillis par l'International Commission, l'effet que l'interruption des attaques contre les navires marchands par la flotte rebelle, à la fin de la guerre, pouvait avoir sur les besoins en provisions alimentaires, l'opinion de la Société des Nations sur l'organisation, ou les perspectives de l'International Commission de poursuivre son travail humanitaire en Espagne après la fin du conflit. NAI, Dept. For. Aff. -200 Series files- 243/7a. 
Joseph Walshe jugèrent opportun de conclure la demande de l'International Commission et de rendre effectif le paiement de la donation avant que l'année fiscale en cours ne se termine. Dans ce but, ils demandèrent à Malcolm de Lilliehöök de leur fournir la plus grande quantité possible d'informations et de solides arguments afin de défendre le don au Dáil; on s'attendait particulièrement à ce que le fait que l'organisation destinerait beaucoup plus de ressources à l'Espagne républicaine plutôt qu'au territoire rebelle, où la pénurie était loin de la crise de subsistance qui touchait le camp loyaliste, soit un sujet sensible. Ainsi, non seulement l'opposition parlementaire pouvait torpiller l'initiative en critiquant dans la Chambre Basse, une fois de plus, la posture adoptée par le Gouvernement face à la guerre d'Espagne, mais certains officiels du ministère des Affaires Étrangères réaffirmèrent aussi leurs réticences. À cet égard, on conserve trois notes à usage interne, rédigées entre les mois d'octobre et novembre de cette même année, qui remettaient en question des éléments concrets de l'opération ou la déconseillaient complètement. Le premier de ces rapports, intitulé Method of paying over our contribution (total £2.000) to the International Commission for the Assistance of Child Refugees in Spain, envisageait la possibilité de réduire de manière significative la somme d'argent promise par le Gouvernement :

As no undertaking has so far been given to the International Commission to pay them any precise amount we are free to give them less without breach of commitment. In view of the fact that most of the few European States who have contributed so far to the Commission's funds have given less tan $£ 1.000$ later, if and when the majority of European States decide to contribute also, or if and when the other contributing States double (or increase considerably) their previous contributions ${ }^{49}$.

La deuxième note, intitulée Question of a contribution to the Commission for the Assistance of Child Refugees in Spain, expose, d'un côté, l'idée de ne donner aucune rétribution à l'organisation. Dans un deuxième temps, elle suggère aussi de faire des dons alimentaires plutôt que monétaires; elle évoque aussi dans son introduction la possible concession des droits de belligérance aux insurgés, une question qui avait soulevé les passions lors des débats parlementaires tenus à la chambre basse un an auparavant :

[...] 4. In short, our position in the whole matter appears to be still unprejudiced. We could, if desired, contribute up to $£ 2.000$ (on the basis of some of the British Dominions' donations) or under $£ 1.000$ (on the basis of what many European countries have given) or give nothing at all on the ground that the Commission is actually spending nearly six times more on

49. Ibid. 
the Barcelona child refugees than on those in Franco Spain. Our whole view of the matter may be altered by events in Spain should belligerent rights be accorded in the near future to General Franco's forces. Undoubtedly, when we were considering the possibility of a contribution the war in Spain seemed less likely to come to a sudden end as it does now.

5. Perhaps an easy solution of the whole problem might be... that we could help the Spanish children with food or other contributions in kind. Such a method of dealing with the plight of those children would probably raise less criticism here than a proposal to send out taxpayer' money to Spain. The purchase by the Government of some hundreds of pounds' worth of butter, soap, dried herrings, etc. here would not only help agriculture and trade in this country to the extent of the amount actually purchased, but might do something also to initiate a taste for Irish products throughout a country which may soon be again in a position to purchase from abroad ${ }^{0}$.

Le troisième message, qui, bien qu'il ne comporte aucun en-tête est le plus long, digresse sur les conséquences de la cession d'un don étant donné l'évolution récente des événements en Espagne sur le terrain militaire. Ce document avertit qu'une telle décision remettrait en question la prétendue neutralité du Saorstát, un autre cheval de bataille sur lequel les discours enflammés au Dáil avaient insisté, prolongerait inutilement la résistance républicaine déjà condamnée à l'échec, et exposerait l'exécutif à une possible réaction défavorable de l'opinion publique irlandaise. En effet, à ce moment du conflit, la pénurie matérielle et le manque d'aliments qui touchait l'arrière-garde républicaine, étaient devenus un outil de premier ordre dont se servaient les commandements nationalistes pour vaincre leur ennemi. Le mémorandum signalait que si des approvisionnements étaient fournis au territoire loyaliste, et d'autant plus si cela était soutenu par d'autres gouvernements, les conditions de vie de la population civile pourraient s'améliorer, gâchant ainsi le blocus de fait que l'armée rebelle avait imposé à l'Espagne républicaine. La remise de l'aide réclamée par l'International Commission pouvait changer, ainsi, le cours de la guerre, en particulier si l'approbation de la demande suscitait à l'étranger une réaction en chaîne de solidarité. D'autre part, compte tenu de la réaction d'opposition citoyenne à une manifestation de soutien à la cause loyaliste dans la localité de Birr, la note soutenait que l'approbation de la demande formulée par l'organisation pouvait provoquer le refus de l'électorat. De même, le fait que la majeure partie de l'envoi ait pour destination le territoire républicain, au lieu d'avoir prévu une répartition équivalente entre les deux camps, menaçait de compromettre l'adhésion du Gouvernement au Pacte de Non-Intervention; la souscription à l'initiative de l'International Commission de 
la part de l'exécutif irlandais pourrait être considérée, en fin de compte, comme un acte d'ingérence dans la guerre civile espagnole. Ainsi l'annonçait le rapport :

1. The circumstances have altered considerably since other Governments agreed to contribute to this scheme. The food position in Republican Spain has now become such a big factor in the whole situation that, if we were now to undertake to supply food to any section of the "Republican" population, we would be open to the charge of committing what would amount in effect to an act of intervention in the Spanish conflict. 2. Within recent months, the reduction of the food supplies of Government Spain has become a vital part of Franco's campaing. He has succeeded in instituting what, if he were granted belligerent rights, would certainly be regarded as an effective blockade. At the moment, it is on this blockade, more than anything else, that the Burgos Government is relaying to bring the war to an end. [...] any scheme involving the supply of food to "Government" Spain, even though it is confined to a particular section of the population, must help to strengthen the Republican Government in its resistance to Franco and, by so doing tend to prolong the conflict. [...] 4. [...] the case against an arrangement under which the Irish Government would itself set up a committee to purchase food and ship it out to Spain is even stronger. It would mean that the Irish Government would be taking a more active and direct part in the supply of food to Spain than any other Government has yet taken; it would carry the implication that the Irish Government agreed with the refusal of belligerent rights and disapproved on humanitarian grounds of the measures of blockade instituted by Franco; and it would create the danger that other European Governments would be encouraged by the Irish precedent to yield to the pressure of their Leftist supporters and take active steps to defeat the purpose of Franco's present campaign. 5. All this is, of course, merely one point of view. But that it is one likely to find fairly general acceptance is suggested by what happened when the Society of Friends tried to hold a dance in Birr to raise funds for objects similar to those of the League Commission. The Gárda opposed the grant of the licence on the ground that "there was an undercurrent of feeling in the town that the fund would be used to help Red Government", and, though the licence was granted, the dance had eventually to be abandoned owing to local opposition $^{51}$.

51. Ibid. Au sujet des débats qui eurent lieu au Dáil autour de la souscription du Pacte de non-intervention par le Gouvernement irlandais, et la concession de la reconnaissance diplomatique des insurgés, voir Gonzalo Butron Prida, "El gobierno irlandés ante la Guerra Civil espańola. Actividad legislativa y debates parlamentarios", Trocadero. Revista de historia moderna y contemporánea, Universidad de Cádiz, No. 3, 1991. 
À la fin du mois de décembre 1938, anticipant l'approbation du Parlement, le Gouvernement irlandais accorda la concession immédiate de 1000 livres sterling à l'International Commission. Le respect du principe de neutralité au moment de fournir l'aide, et l'acceptation du plan par les deux camps opposés, étaient les conditions sine qua non que l'organisation devait respecter, selon les termes de l'attribution fixés par Dublin. Les responsables de l'organisme saluèrent chaleureusement le geste et rappelèrent, ainsi que l'exprime une lettre remise à Joseph Walshe, "that the task that is still confronting the International Commission is of such urgency and magnitude as to demand regular and substantial contributions from all Governments ». En effet, du point de vue humanitaire, la situation sur le terrain continuait à se détériorer. Ainsi que le soulignent les rapports remis par le Délégué irlandais à Genève au Département des Affaires Étrangères en février 1939, " the cessation of attacks on shipping outside the limit has not done away with the shortage of foodstuffs. There is all the time the blockade, and of course there is a shortage of transport". Le travail de l'International Commission, qui continuait à se dérouler principalement en Catalogne et dans le centre de l'Espagne, dut s'étendre aux enfants déplacés qui commençaient à se regrouper dans le sud de la France. À tel point que, pour pouvoir faire face à cette nouvelle urgence, l'organisation transféra son siège à Paris et étendit la collecte, au-delà des organismes gouvernementaux, au public en général. Des nations comme la Pologne ou l'Égypte rejoignirent la collecte internationale, d'autres, comme les Pays-Bas, les États-Unis ou le Canada, apportèrent une contribution en nature. La fatigue accumulée par les déplacements constants et l'ampleur de la tâche forcèrent la succession de Malcolm de Lilliehöök en tant que directeur de terrain par l'américain Howard E. Kershner, qui accompagna au milieu du mois le président de l'International Commission à Burgos, où ils eurent une entrevue avec Franco. Les conditions de la population civile dans les deux arrière-gardes étaient si graves, que le Généralissime accepta que l'organisme étende ses opérations à toutes les régions du pays qui se trouvaient sous son contrôle, en particulier en Catalogne, tout en approuvant le travail de l'organisation sur le territoire républicain ainsi que dans le sud de la France. De plus, selon le document dactylographié de Cremins, il permettrait le passage par la mer des approvisionnements destinés au territoire de la Meseta aux mains des loyalistes; c'est-à-dire, " that in cases in which ships may be beld up within the limit, those containing supplies for the Commission's work will be allowed through. Further, that there will be no bombing of such ships». Enfin, le chef militaire des insurgés estimait que, même si la guerre terminait ipso facto, le peuple espagnol aurait besoin de l'aide de l'organisme au moins durant six mois de plus $^{52}$. Malgré tout, les besoins urgents auxquels l'International Commission dut

52. Le rapport soutenait, de même, que le général assura aux représentants de l'organisation que le nouveau 
faire face, à partir de ce moment, obligèrent ces dirigeants à réclamer, auprès des autorités irlandaises, la remise des 1000 livres sterling complémentaires qu'elles avaient promis de donner.

Les porte-parole de l'organisation firent pression, de nouveau, sur Dublin. Le Foreign Office et le Dominions Office britanniques en firent de même; ainsi, en guise d'exemple, nous pouvons recopier un extrait de la note reçue par le HautCommissariat irlandais à Londres, au début du mois de mars 1939, de la part du Vicomte de Halifax :

I am further to inform you that His Majesty's Government consider it desirable, in the interests of the Commission's relations with General Franco's Administration that no time should be lost in arranging for the distribution of a portion of the Commission's supplies in those parts of Spain which are in General Franco's possession, and particularly in Barcelona, where the need is understood to be extremely urgent ${ }^{33}$.

À cette même époque, le ministère des Affaires Étrangères envisageait encore la possibilité de ne pas procéder au second paiement ou de diminuer le montant de l'aide. Cependant, l'engagement pris s'imposait comme un fait accompli, les agents du ministère commençant ainsi à se demander quel type d'aide impliquerait des coûts politiques plus raisonnables, à ce moment-là, une contribution en nature. La note suivante, remise le 4 mars à Joseph Walshe par un de ses subalternes, résume ce cas de conscience :

I quite agree with your view regarding the final moitey of our contribution to the Spanish Child Refugee Commission. It would undoubtedly be best to take no hasty action before further pressure is brought to bear on us, yet there would seem but little hope of eventually evading payment, in some form, of the full amount sanctioned by the Dáil. Perhaps, when the matter seems somewhat riper, we might act... In any event, the case for a contribution in kind is now definitely more arguable. If the Minister were to agree, we might consult the Departments of Agriculture and Industry \& Commerce concerning the produce or manufactured goods most suitable, from their points of view, for shipment to Spain ${ }^{54}$.

régime mettrait fin aux exportations de blé vers l'Allemagne tant que perdurerait la pénurie alimentaire. La nature de ces échanges avait été récemment révélée à la presse, causant la stupeur parmi l'opinion publique internationale. Sans aucun doute, l'Italie recevait, en compensation de l'aide militaire qu'elle fournissait, des produits alimentaires provenant du territoire nationaliste, de son côté, l'Allemagne se satisfaisait de l'envoi, sous le même prétexte, de matières primaires. Évidemment, les autorités rebelles durent aller au-devant de ces nouvelles. NAI, Dept. For. Aff. -200 Series files- 243/7a.

53. Ibid.

54. Ibid. 
Quelques jours plus tard le Secrétaire adjoint du ministère des Affaires Étrangères, F. H. Boland, ordonna au représentant irlandais à Paris de l'époque, Seán Murphy, de faire part aux dirigeants de l'International Commission de la décision du gouvernement : quelques semaines plus tôt, le Dáil avait approuvé, sous la recommandation de Valera, la concession des 1000 livres sterling complémentaires. L'argent serait remis à condition que les responsables de l'organisation acceptent d'en dépenser les trois quarts en Irlande, en achetant des produits élaborés ou manufacturés dans l'île; plusieurs ministères aideraient les commissaires de l'association dans cette tâche. L'année fiscale en cours se terminant à la fin de ce même mois de mars, la contribution serait remise de manière imminente, dans le cas contraire le Parlement devrait approuver de nouveau la mesure à l'ouverture de la nouvelle année fiscale. Le 24 mars 1939, Howard E. Kershner reçut le chèque promis par le gouvernement, ainsi qu'une liste de possibles fournisseurs irlandais et les prix auxquels les produits seraient vendus à l'organisation. Le directeur de l'International Commission se rendit à Dublin début avril afin de concrétiser l'achat. Le Département d'Agriculture ainsi que celui d'Industrie et Commerce lui apportèrent leur aide le temps de son séjour dans l'île. Durant cette visite, et ainsi qu'il l'avait auparavant annoncé par écrit, Kershner fit savoir aux officiels du ministère des Affaires Étrangères sa volonté de demander à De Valera que le Gouvernement irlandais continue à fournir de la nourriture aux réfugiés à l'avenir : "In view of the wide spread starvation existing there, which condition will probably grow worse rather than better during the next 2 or 3 months, I am hoping that your Government may become interested in making available additional quantities of food-stuffs for the innocent war victims in Spain ". À cette occasion comme lors de ses demandes ultérieures, la réponse fut toujours la même : " circumstances do not permit the Minister to recommend further financial contributions to your funds during the present financial year ${ }^{55}$ ".

Les approvisionnements, des vêtements et des chaussures pour enfants, du lait concentré en poudre et des produits comme de la margarine et de la farine d'orge, furent embarqués à destination de Bilbao, où ils furent pris en charge par l'Auxilio Social, une organisation franquiste dirigée par Javier de Bedoya; le Sous-Secrétaire du ministère des Affaires Étrangères nationaliste, le général Espinoza Monteros, garantissait personnellement la protection et l'immunité de l'équipe détachée sur le terrain par le délégué de l'International Commission, David Blickenstaff.

En 1939, l'organisation continua à aider la population espagnole, en priorité les enfants, sur le territoire national, sous contrôle des rebelles à partir du mois d'avril, comme en France et en Afrique du Nord. Les chancelleries européennes, et en particulier le Royaume-Uni, continuèrent à financer, dans la mesure du

55. Ibid. 
possible, les coûts de la campagne humanitaire maintenue par l'International Commission. À ce sujet, le Dominions Office continua à faire pression sur le Haut-Commissariat irlandais à Londres pour que son Gouvernement rejoigne l'initiative. À plusieurs reprises, les responsables de l'organisation en firent de même. Voici, à titre d'exemple, un court fragment de la lettre que Hanson et Kershner firent parvenir à De Valera en août de cette année : "[...] it should be emphasised that Winter is approaching. Heavier clothing and blankets will be necessary if the lives of these people are to be preserved. Many of them are children; some thousands are orphans, almost all are scattered fragments of families, without home, country or friends ${ }^{56} "$.

À l'automne, l'International Commission transmit à la Légation irlandaise de Paris une offre d'achat adressée aux entrepreneurs textiles de l'île, dans le but d'acquérir une quantité considérable de couvertures pour les réfugiés. Le Département d'Industrie et du Commerce interrogea quelques enseignes, mais toutes refusèrent la proposition. Au début de l'année 1940, Howard E. Kershner réclama encore à De Valera la participation de son Gouvernement à la campagne solidaire. À cette date, l'organisation venait d'affréter 575 tonnes de lait en poudre pour l'Espagne, et se préparait à envoyer six cliniques mobiles sur le terrain ainsi qu'un nouveau chargement de provisions. Malgré tout, l'activité de l'International Commission sur le sol espagnol touchait à sa fin, puisque la fin des batailles et le rationnement des aliments que les autorités nationalistes avaient mis en place permettaient de prévoir, malgré la misère dans laquelle se trouvait le pays, la subsistance des enfants espagnols. À partir de ce moment, l'organisation humanitaire concentrerait ses efforts en France et en Afrique du Nord, où les conditions de vie dans les camps de réfugiés républicains étaient très précaires ${ }^{57}$. Cependant, après le versement des $1000 £$ complémentaires au mois de mars de l'année antérieure, le gouvernement de l'Éire n'apporta aucune autre aide à l'organisation, ni en espèces ni en nature.

Il faut souligner, enfin, qu'en mai 1939, l'Organisation internationale pour le respect du droit d'asile et l'aide des réfugiés politiques fit parvenir une lettre à Joseph Walshe depuis son siège à Paris, dans laquelle elle priait les autorités du Saorstát d'accueillir quelques-uns des plus de 350000 réfugiés espagnols qui se trouvaient en France. Le Secrétaire du ministère des Affaires Étrangères conclut l'affaire par une note qu'il fit parvenir à la Légation irlandaise de Paris, où nous pouvons lire:

56. Concernant la correspondance entre la Dominions Office et le bureau du Haut-Commissariat irlandais à Londres, voir la circulaire du 13 mai 1939 que ce dernier envoya au Secrétaire du Département des Affaires Étrangères. Quant aux échanges postaux entre l'International Commission et les autorités irlandaises durant l'année 1939, voir, entre autres, les lettres ou rapports du 12 et 21 août 1939 ainsi que du 13 et 20 octobre 1939. Ibid.

57. Voir la lettre envoyée par Howard E. Kershner depuis Paris à Eamon de Valera le 20 janvier 1940. Ibid. 
En plus du nom de l'organisation, fortement suspect en soi, vous déduirez à la lecture de la lettre que M. Perrin souhaiterait que notre Gouvernement donne du travail à un certain nombre de rouges espagnols qui apparemment ne souhaitent pas retourner dans leur propre pays. $\mathrm{Au}-$ riez-vous l'amabilité d'informer M. Perrin que, étant donné que l'Irlande souffre d'un grand problème de chômage, elle se trouve dans l'incapacité de pouvoir fournir un emploi aux étrangers ${ }^{58}$ ?

L'exécutif de Dublin n'évoqua plus la question et n'établit jamais aucun contact avec cette organisation.

Ainsi que nous le présentions dans l'introduction, le lecteur aura pu se rendre compte que le Gouvernement irlandais refusa de coopérer avec les organismes qu'il pouvait accuser de sympathies gauchistes. La crainte d'être associé, par une partie de l'électorat, à une attitude connivente envers la République espagnole, suffisait pour justifier cette position. Cela détermina la réponse de Dublin aux demandes d'aide formulées par le National Joint Committee for Spanish Relief, l'Irish Foodship for Spain et l'Organisation internationale pour le respect du droit d'asile et l'aide des réfugiés politiques. La réputation internationale et la pression de l'Angleterre finirent de convaincre l'exécutif du Fianna Fáil, malgré la réticence de quelques ministères, de l'intérêt de répondre favorablement à la demande de l'International Commission for the Assistance of Child Refugees in Spain. À son tour, le faux pas diplomatique survenu au sujet de la Croix-Rouge Internationale met en relief la réticence du cabinet de Valera à financer les activités d'aides au peuple espagnol, sauf dans le cas, ainsi que cela se produisit avec la demande de l'International Commission for the Assistance of Child Refugees in Spain, où l'impératif politique les rendrait inéluctables.

58. Dermot Keogh, Ireland and Europe 1919-1989, Cork \& Dublin, Hibernian University Press, 1990, p. 103106 [traduit de l'anglais]. 